\title{
Faktor-Faktor Penentu Studentifikasi di Kawasan Sekitar ITS Sukolilo
}

\author{
Ahmad Zuhdi dan Putu Gde Ariastita \\ Departemen Perencanaan Wilayah dan Kota, Fakultas Arsitektur, Desain, dan Perencanaan \\ Institut Teknologi Sepuluh Nopember (ITS) \\ E-mail: ariastita@urplan.its.ac.id
}

\begin{abstract}
Abstrak-Studentifikasi dapat dipahami sebagai proses yang disebabkan oleh konsentrasi hunian pelajar berpendidikan tinggi yang diiringi dengan perubahan struktur spasial yang berdampak sosial, ekonomi, budaya dan fisik pada kawasan lokal lembaga pendidikan tinggi. Data Kawasan Sekitar Kampus ITS menunjukkan terjadi perubahan kavling yang signifikan, kenaikan harga tanah, pertambahan penduduk muda berlatar belakang asal yang bervariasi, hingga tumbuhnya fasilitas akomodasi mahasiswa. Sehingga studentifikasi menjadi hal yang tidak dapat dielakkan bagi kawasan. Untuk mengantisipasi efek studentifikasi maka dibutuhkan suatu penjelasan logis dan ilmiah mengenai pola dari gejala studentifikasi. Penelitian ini bertujuan untuk menentukan faktor-faktor penentu kriteria dari gejala studentifikasi yang terdapat di Kawasan Sekitar Kampus ITS. Pendekatan yang digunakan adalah kualitatif-kuantitaif dengan metode wawancara delphi.

Hasil analisa menunjukkan faktor-faktor penentu studentifikasi pada kawasan Sekitar Kampus ITS Sukolilo antara lain: Kebutuhan Ruang (fisik), Densitas/Kepadatan Penduduk (fisik), Kelengkapan Fasilitas Lingkungan (fisik), Keberadaan Induk Semang pada Hunian (sosial), Interaksi Antara Mahasiswa dan Masyarakat (sosial), Pertambahan Penduduk Muda (sosial), Bauran Mahasiswa dan Masyarakat (budaya), Kepemilikan Properti (ekonomi), Indekos sebagai Investasi (ekonomi), Kepemilikan Usaha Lain (ekonomi), Harga Jual Tanah (ekonomi).
\end{abstract}

Kata Kunci- Studentifikasi, Gentrifikasi, Kawasan Sekitar Kampus ITS.

\section{PENDAHULUAN}

$S^{1}$ TUDENTIFIKASI dapat dipahami sebagai proses yang disebabkan oleh konsentrasi hunian pelajar berpendidikan tinggi yang diiringi dengan perubahan struktur spasial yang berdampak sosial, ekonomi, budaya dan fisik pada kawasan lokal lembaga pendidikan tinggi[1].

Studentifikasi memiliki dampak berupa revitalisasi kawasan dan membawa terbukanya kesempatan ekonomi. Selain itu, studentifikasi juga menyebabkan segregasi sosial, berkembangnya isu konflik sosial dengan penduduk asli, serta membawa karakter kawasan student ghettoe yang ramai saat periode akademik dan seperti kota kosong ketika musim liburan[2]. Gejala studentifikasi juga memiliki pengaruh terhadap struktur ruang[3].

Masuknya mahasiswa pada suatu kawasan menjadi salah satu penyebab terjadinya perubahan lahan di kawasan Sekitar Kampus ITS[4]. Dalam penelitian tersebut perubahan lahan terlihat mengalami pertambahan signifikan dimana unit kavling tumbuh $72 \%$ pada interval tahun 1996-2014. Pada tahun 1996 berjumlah 10.767 unit menjadi 18.472 unit pada tahun 2014 yang didominasi penggunaan pondokan (hunian) dan perdagangan jasa. Bagi penduduk asli yang menetap, hal ini memberikan desakan (ekonomi dan sosial) untuk beradaptasi atau memilih berpindah ke daerah lain (karena tidak mampu beradaptasi). Sehingga gejala studentifikasi pada prinsipnya akan membawa perubahan proporsi penggunaan lahan yang didominasi oleh mahasiswa dan kegiatan akomodasi bagi mahasiswa.

Kawasan Sekitar ITS merupakan kawasan strategis dengan wujud ruang cluster pendidikan yang diarahkan untuk kegiatan utama pendidikan dan perdagangan-jasa[5]. UP. Kertajaya merupakan kawasan Surabaya Timur yang melingkupi Kecamatan Sukolilo dimana Kampus Utama ITS berada. Masuknya kelas mahasiswa di kawasan sekitar ITS membawa lonjakan permintaan hunian untuk kelas mahasiswa. Jumlah Mahasiswa yang diterima di ITS pada tahun 2017 saja berjumlah 1.059 jalur SNMPTN, 1.366 jalur SBMPTN, dan 1026 jalur PKM, dengan total 3.451. Para mahasiswa akan berdomisili di area kampus (on campus) dan di luar kampus (off campus). Daerah on campus adalah daerah asrama (purposed-built) [6] yang diperuntukkan bagi mahasiswa tingkat pertama dan Perumahan Dosen (Perumdos). Sementara untuk mahasiswa off campus tersebar di kelurahan di sekitar ITS. Hal ini menunjukan besarnya okupansi mahasiswa pada kawasan Sekitar ITS itu sendiri.

Data demografi kawasan Sekitar ITS yang terdiri dari lima kelurahan terdekat ITS (Keputih, Gebang Putih, Mulyorejo, Kejawan Keputih Tambak, dan Kalisari) menunjukkan setidaknya pada tahun 2013-2015 jumlah penduduk Kawasan Sekitar ITS meningkat 7\%. Hal ini mengindikasikan pertumbuhan yang cukup tinggi di kawasan ini. Sementara untuk komposisi penduduk pindah dan datang menunjukkan angka 925 jiwa dan 1.611 jiwa pada tahun 2013. Pada tahun 2015, jumlah penduduk pindah naik 45\% menjadi 1.345 jiwa. Sementara penduduk datang naik 26\% menjadi 2.037 jiwa[7]. Hal ini menunjukkan perpindahan penduduk yang lebih besar daripada penduduk yang masuk ke kawasan Sekitar ITS dari penduduk yang teregistrasi di Dinas Pencatatan Sipil Surabaya. Secara tidak langsung dapat disimpulkan terjadi indikasi tergesernya masyarakat pada kawasan Sekitar ITS.

Penelitian mengenai Studentifikasi pertama kali dilakukan di Leeds, Brighton [8], Orono [9], Kuala Lumpur [10], Yogya [11], dan Semarang [12] dapat disimpulkan bahwa kawasan yang memiliki Perguruan Tinggi mengalami fenomena studentifikasi. Gejala studentifikasi tersebut berdampak positif dan negatif sehingga dibutuhkan suatu antisipasi untuk menekan dampak negatif dan positifnya. Sementara, keadaan eksisting dilihat dari data empiris menunjukkan indikasi terjadinya studentifikasi di Kawasan Sekitar ITS. Perubahan lahan dan kavling yang didominasi mahasiswa, berkembangnya indekos dan perdagangan jasa pendukung mahasiswa, hingga perubahan budaya agregat yang tercipta akibat masuknya mahasiswa ke dalam kawasan. Keadaan ini mengindikasikan adanya gejala studentifikasi. Apabila tidak 
diantisipasi dampaknya akan mengganggu kondusifitas kawasan sebagai kawasan perguruan tinggi dan juga sebagai tempat hidup masyarakat.

Sementara untuk kawasan Kampus ITS sendiri belum terdapat penjelasan secara ilmiah dan terstruktur mengenai fenomena studentifikasi. Maka perlu melakukan penyelidikan tentang gejala studentifikasi di kawasan Sekitar ITS beserta dampaknya bagi masyarakat dan kawasan. Oleh karena itu, diperlukan suatu penelitian untuk menangkap fenomena studentifikasi ini. Jurnal ini akan menjelaskan tahap awal dari perumusan pola studentifikasi kawasan Sekitar Kampus ITS Surabaya. Jurnal ini bertujuan untuk merumuskan faktor-faktor penentu Studentifikasi pada kawasan Sekitar Kampus ITS Sukolilo.

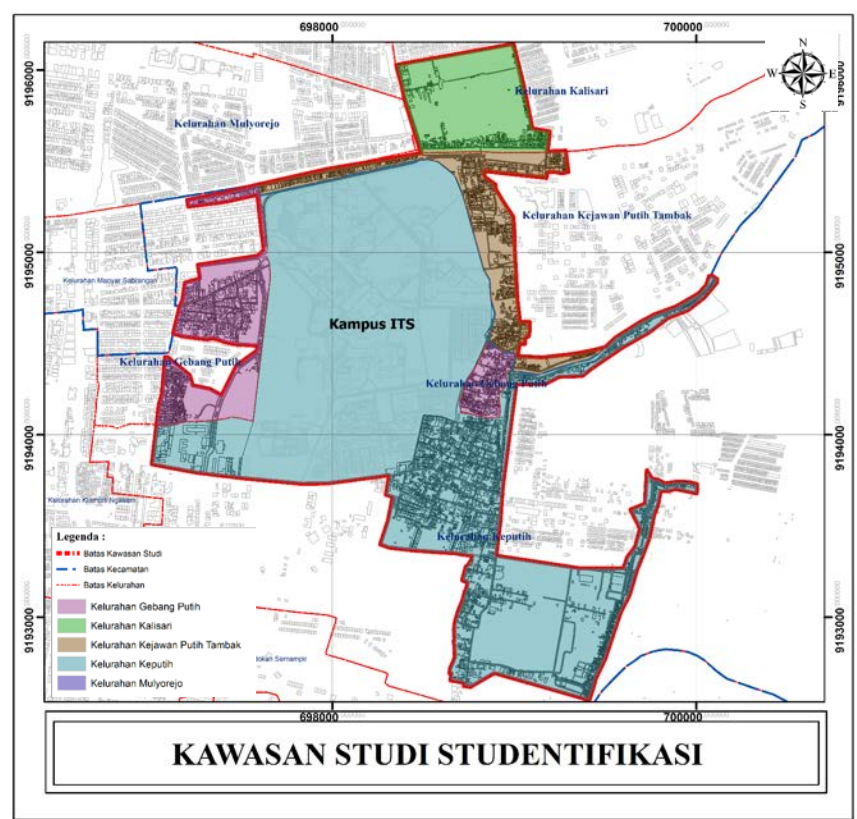

Gambar 1. Ruang Lingkup Penenlitian Studentifikasi Kawasan Sekitar Kampus ITS

\section{METODE PENELITIAN}

\section{A. Jenis dan Pendekatan Penelitian}

Penelitian ini menggunakan rasionalistik[13]. Sementara jenis penelitian dalam penelitian ini adalah deskripti kualitatif.

\section{B. Variabel Penelitian}

Variabel penelitian yang dugunakan dalam menentukan faktor-faktor yang berpengaruh dalam studentifikasi di kawasan sekitar kampus ITS Sukolilo, antara lain: Tingkat diversifikasi aktifitas (fisik), Karakteristik tampilan bangunan (fisik), Kebersihan lingkungan (fisik), Keberadaan bangunan tertentu khas mahasiswa (fisik), Tingkat penyediaan hunian indekos dengan tuan rumah (sosial), Tingkat penyediaan hunian indekos tanpa tuan rumah (sosial), Tingkat penyediaan hunian purpose-built (sosial), Interaksi antara mahasiswa dan masyarakat (sosial), Pertambahan Penduduk Muda (sosial), Tingkat keramaian kawasan (budaya), Bauran mahasiswa dan masyarakat (budaya), Kepemilikan pondokan (ekonomi), Kepemilikan usaha lain (ekonomi), Harga Jual Tanah (ekonomi).

\section{Menentukan Faktor-Faktor Penentu Studentifikasi Menggunakan Analisis Delphi}

Analisis Delphi merupakan analisis dengan cara mengumpulkan pendapat dari orang tertentu terkait topik tertentu. Adapun Expert/Responden dari penelitian ini ditetapkan dari dua elemen yaitu: Tokoh Masyarakat dan Akademisi. Adapun tahapan Analisa Delphi dapat dilihat pada bagan berikut:

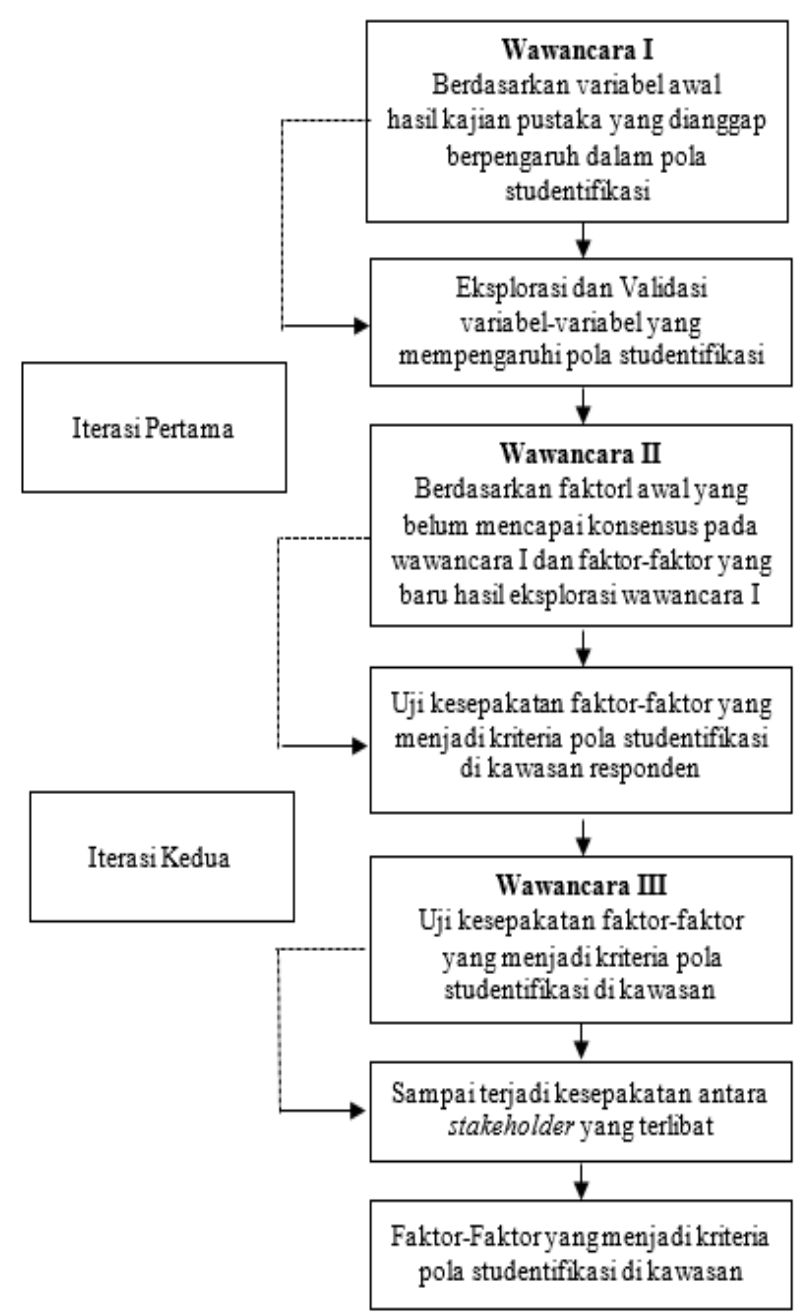

Gambar 2. Tahapan Analisa Delphi Studentifikasi Kawasan Sekitar ITS

1) Wawancara Stakeholder Untuk Eksplorasi Faktor

Untuk mengetahui faktor-faktor yang berpengaruh dalam pola studemtifikasi di Kawasan Sekitar ITS Surabaya, maka perlu dilakukan eksplorasi dan validasi faktor terhadap stakeholder kunci melalui wawancara semi terstruktur. Wawancara semi terstruktur dapat dilakukan dengan formal maupun informal tergantung lapangan dan responden. Pertanyaan wawancara berupa pernyataan penilaian terhadap faktor-faktor yang telah dirumuskan berdasarkan hasil identifikasi literatur, serta pertanyaan terbuka yang dapat berkembang untuk memperoleh informasi yang lebih lengkap.

2) Reduksi dan Tampilan Data Hasil Wawancara

Reduksi data adalah proses analisis untuk memilih, memusatkan perhatian, menyederhanakan, serta mengabstraksikan dan mentransformasikan data yang muncul dari catatan-catatan di lapangan[13]. Dari ringkasan hasil wawancara dan proses reduksi, akan didapatkan faktorfaktor yang menentukan perkembangan lahan permukiman, berdasarkan opini yang diutarakan oleh masing-masing responden. Faktor-faktor tersebut kemudian dijadikan sebagai masukan bagi tahap selanjutnya 


\section{3) Iterasi dan Penarikan Kesimpulan}

Iterasi ditujukan untuk memastikan, apakah faktor-faktor hasil ringkasan wawancara sesuai dengan maksud yang diberikan oleh masing-masing stakeholder. Dari hasil identifikasi faktor berdasarkan opini tiap-tiap stakeholder tersebut, kemudian disederhanakan atau dikelompokkan secara substansial. Terhadap faktor lain yang belum disebutkan oleh semua stakeholder, akan dilakukan konfrimasi atau cross check kepada responden yang lainnya. Sehingga dapat dirumuskan apa saja faktor-faktor yang menjadi kriteria pola studentifikasi Kawasan Sekitar Kampus ITS.

\section{HASIL DAN DISKUSI}

\section{A. Penentuan Variabel Melalui Tinjauan Pustaka}

Variabel penelitian faktor-fakor penentu gejala studentifikasi di Kawasan Sekitar Kampus ITS , sebagai berikut:

Tabel 1.

Penentuan Variabel Faktor Melalui Tinjauan Pustaka

\begin{tabular}{|c|c|c|c|c|c|c|}
\hline Variabel & $\begin{array}{c}\text { Grace Suradi } \\
\text { (2013) }\end{array}$ & $\begin{array}{c}\text { Prayoga } \\
\text { (2014) }\end{array}$ & $\begin{array}{l}\text { Sabri et al. } \\
\text { (2008) }\end{array}$ & $\begin{array}{c}\text { Phil Hubbart } \\
\text { (2009) }\end{array}$ & $\begin{array}{c}\text { Anderson } \\
\text { (2011) }\end{array}$ & $\begin{array}{c}\text { Joanna Louise } \\
\text { (2010) }\end{array}$ \\
\hline Tingkat diversifikasi aktifitas & $\mathrm{V}$ & $\mathrm{V}$ & & & & \\
\hline Karakteristik tampilan bangunan & $\mathrm{V}$ & $\mathrm{V}$ & V & $\mathrm{V}$ & $\mathrm{V}$ & $\mathrm{V}$ \\
\hline Kebersihan lingkungan & $\mathrm{V}$ & & & $\mathrm{V}$ & $\mathrm{V}$ & $\mathrm{V}$ \\
\hline Keberadaan bangunan tertentu khas mahasiswa & & & & $\mathrm{V}$ & $\mathrm{V}$ & $\mathrm{V}$ \\
\hline Tingkat penyediaan hunian indekos dengan tuan rumah & $\mathrm{V}$ & & & $\mathrm{V}$ & $\mathrm{V}$ & $\mathrm{V}$ \\
\hline Tingkat penyediaan hunian indekos tanpa tuan rumah & $\mathrm{V}$ & & & $\mathrm{V}$ & $\mathrm{V}$ & $\mathrm{V}$ \\
\hline Tingkat penyediaan hunian purpose-built & & & & $\mathrm{V}$ & & $\mathrm{V}$ \\
\hline Interaksi antara mahasiswa dan masyarakat & $\mathrm{V}$ & $\mathrm{V}$ & & $\mathrm{V}$ & $\mathrm{V}$ & $\mathrm{V}$ \\
\hline Pertambahan penduduk muda & $\mathrm{V}$ & V & V & $\mathrm{V}$ & V & V \\
\hline Tingkat keramaian kawasan & & & & $\mathrm{V}$ & $\mathrm{V}$ & $\mathrm{V}$ \\
\hline Bauran mahasiswa dan masyarakat & & V & & & & \\
\hline Kepemilikan pondokan & V & V & V & $\mathrm{V}$ & $\mathrm{V}$ & $\mathrm{V}$ \\
\hline Kepemilikan usaha lain & $\mathrm{V}$ & V & & & & \\
\hline Peningkatan atau penurunan harga tanah & $\mathrm{V}$ & V & V & & V & \\
\hline
\end{tabular}

Tabel 2.

Variabel dan Definisi Operasional

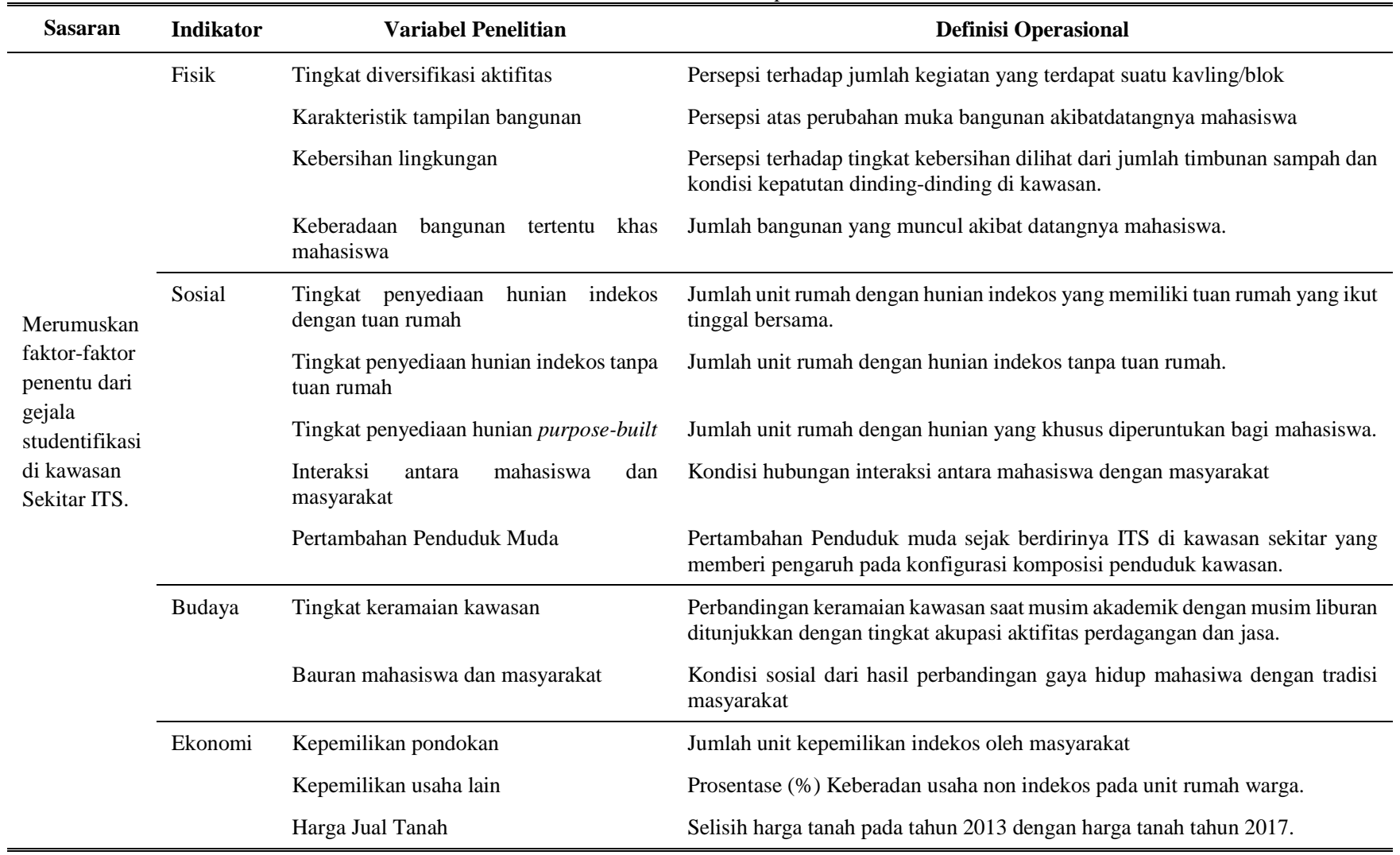


Dari Tabel 1 kemudian dijabarkan menjadi variabel seperti pada Tabel 2.

\section{B. Penentuan Faktor-Faktor Penentu Kriteria Studentifikasi Kawasan Sekitar Kampus ITS Sukolilo.}

Berdasarkan hasil tinjauan pustaka didapatkan faktor-aktor yang berpengaruh dapat dirujuk dengan indikator berikut :

1) Indikator Fisik

Peningkatan eksternal fisik lingkungan sebagai properti karena dikonversi menjadi tempat tinggal pelajar, akan membawa penurunan kualitas fisik dan lingkungan, yang berkaitan dengan konteks lokal.

\section{2) Indikator Sosial}

Pergantian kelompok penduduk asli dengan penghuni sementara yang muda dan lajang, grup kelas menengah; membawa pola baru dalam konsentrasi dan segregasi sosial.

3) Indikator Budaya

Berkumpulnya pemuda dengan beragam budaya, gaya hidup, serta pola konsumsi antara satu dan lainnya, yang berhubungan dengan infrastruktur yang terkait dengan barang dan jasa.

4) Indikator Ekonomi

Studentifikasi melibatkan inflasi harga properti, yang berkaitan dengan rekomodifikasi dari "keluarga tunggal” atau pengemasan ulang rumah pribadi untuk memenuhi kebutuhan permukiman bagi pelajar.Hal ini menyebabkan dominasi kepemilikan properti oleh pihak swasta dan penurunan kepemilikan pribadi.

Tabel 3

Rekapitulasi Respon Expert dalam Analisa Delphi

\begin{tabular}{|c|c|c|c|c|c|}
\hline Indikator & Variabel & R1 & $\mathbf{R} 2$ & R3 & Keterangan \\
\hline \multirow[t]{4}{*}{ Fisik } & Kebutuhan Ruang & $\mathrm{P}$ & $\mathrm{P}$ & $\mathrm{P}$ & $\begin{array}{l}\text { Konsensus di Putaran } \\
\text { Ke-2 }\end{array}$ \\
\hline & Densitas & $\mathrm{P}$ & $\mathrm{P}$ & $\mathrm{P}$ & $\begin{array}{l}\text { Konsensus di Putaran } \\
\text { Ke-3 }\end{array}$ \\
\hline & $\begin{array}{l}\text { Kebersihan } \\
\text { Lingkungan }\end{array}$ & $\mathrm{P}$ & $\mathbf{T P}$ & $\mathbf{T P}$ & DIREDUKSI \\
\hline & $\begin{array}{l}\text { Kelengkapan } \\
\text { Fasilitas Lingkungan }\end{array}$ & $\mathrm{P}$ & $\mathrm{P}$ & $\mathrm{P}$ & $\begin{array}{l}\text { Konsensus di Putaran } \\
\text { Ke-3 }\end{array}$ \\
\hline \multirow[t]{3}{*}{ Sosial } & $\begin{array}{l}\text { Keberadaan Induk } \\
\text { Semang pada Hunian }\end{array}$ & $\mathrm{P}$ & $\mathrm{P}$ & $\mathbf{T P}$ & $\begin{array}{l}\text { Konsensus di Putaran } \\
\text { Ke-3 }\end{array}$ \\
\hline & $\begin{array}{l}\text { Interaksi Antara } \\
\text { Mahasiswa dan } \\
\text { Masyarakat }\end{array}$ & $\mathrm{P}$ & $\mathbf{T P}$ & $\mathrm{P}$ & $\begin{array}{l}\text { Konsensus di Putaran } \\
\text { Ke-3 }\end{array}$ \\
\hline & $\begin{array}{l}\text { Pertambahan } \\
\text { Penduduk Muda }\end{array}$ & $\mathrm{P}$ & $\mathrm{P}$ & $\mathrm{P}$ & $\begin{array}{l}\text { Konsensus di Putaran } \\
\text { Ke-2 }\end{array}$ \\
\hline Budaya & $\begin{array}{l}\text { Bauran Mahasiswa } \\
\text { dan Masyarakat }\end{array}$ & $\mathbf{T P}$ & $\mathrm{P}$ & $\mathrm{P}$ & $\begin{array}{l}\text { Konsensus di Putaran } \\
\text { Ke-3 }\end{array}$ \\
\hline \multirow[t]{4}{*}{ Ekonomi } & $\begin{array}{l}\text { Kepemilikan } \\
\text { Properti }\end{array}$ & $\mathrm{P}$ & $\mathrm{P}$ & $\mathbf{T P}$ & $\begin{array}{l}\text { Konsensus di Putaran } \\
\text { Ke-3 }\end{array}$ \\
\hline & $\begin{array}{l}\text { Indekos Sebagai } \\
\text { Investasi }\end{array}$ & $\mathrm{P}$ & $\mathrm{P}$ & $\mathrm{P}$ & $\begin{array}{l}\text { Konsensus di Putaran } \\
\text { Ke-2 }\end{array}$ \\
\hline & $\begin{array}{l}\text { Kepemilikan Usaha } \\
\text { Lain }\end{array}$ & $\mathrm{P}$ & $\mathbf{T P}$ & $\mathrm{P}$ & $\begin{array}{l}\text { Konsensus di Putaran } \\
\text { Ke-3 }\end{array}$ \\
\hline & Harga Jual Tanah & $\mathrm{P}$ & $\mathrm{P}$ & $\mathbf{T P}$ & $\begin{array}{l}\text { Konsensus di Putaran } \\
\text { Ke-3 }\end{array}$ \\
\hline
\end{tabular}

Keterangan: $\mathrm{P}$ = Pengaruh, TP = Tidak Pengaruh. R1=Masyarakat Asli, R2= Ahli Perumahan, R3= Ahli Tata Ruang.

Pada delphi putaran pertama terdapat reduksi terhadap 3 variabel yaitu: Tingkat Penyediaan Hunian Indekos Tanpa Tuan Rumah (Sosial), Tingkat Penyediaan Hunian Purposebuilt (Sosial), Tingkat Keramaian Kawasan (Budaya). Alasan dilakukan reduksi adalah ketiga variabel di atas telah tercakup dalam variabel lainnya sehingga lebih baik untuk direduksi. Sementara pada putran kedua terjadi perubahan pada variabel indikator fisik yaitu Tingkat Diversifikasi Aktifitas yang kemudian diganti menjadi variabel Kebutuhan Ruang.

Sementara pda putaran ketiga ditujukan pada konfirmasi saja atas pendapat masing-masing expert. Hasilnya hanya terdapat sau variabel yang direduksi yaitu variabel Kebersihan Lingkungan.

Berikut ini merupakan hasil sintesa penentuan analisis Delphi:

Tabel 4.

Hasil Sintesa Analisa Delphi

\begin{tabular}{lcl}
\hline \hline Indikator & Variabel & \multicolumn{1}{c}{ Definisi Operasional } \\
\hline Fisik & Kebutuhan Ruang & $\begin{array}{l}\text { Luasan ruang publik dan ruang sosial } \\
\text { yang diperebutkan oleh mahasiswa dan } \\
\text { masyarakat. }\end{array}$
\end{tabular}

Densitas/Kepadatan Kepadatan penduduk pada suatu Penduduk kawasan yang berupa penambahan lantai bangunan dan kerapatan bangunan.

Kelengkapan Pertambahan fasilitas sosial-umum dan Fasilitas Lingkungan prasarana kawasan.

Sosial Keberadaan Induk Pertambahan penduduk asli yang
Semang pada memiliki penambahan fungsi sosial Hunian menjadi penanggunjawab mahasiswa.

Interaksi Antara Kondisi hubungan interaksi antara Mahasiswa dan mahasiswa dengan masyarakat

Masyarakat

Pertambahan Pertambahan Penduduk muda sejak Penduduk Muda berdirinya ITS di kawasan sekitar yang memberi pengaruh pada konfigurasi komposisi penduduk kawasan.

Budaya Bauran Mahasiswa Kondisi sosial dari hasil perbandingan dan Masyarakat gaya hidup mahasiwa dengan tradisi masyarakat

Ekonomi Kepemilikan Kepemilikan properti pada kawasan Properti yang dimiliki oleh orang yang tidak bertempat tinggal di kawasan (orang luar).

Indekos sebagai Perubahan rumah/hunian penduduk asli Investasi yang dijadikan indekos dengan motif penambah penghasilan (BusinessOriented)

Kepemilikan Usaha Prosentase Keberadan usaha non Lain indekos pada unit rumah warga.

Harga Jual Tanah Perubahan harga jual tanah pada kawasan sejak berdirinya ITS Sukolilo.

Tabel 4 menunjukkan terdapat 11 (sebelas) variabel yang menjadi faktor-faktor penentu gejala studentifikasi kawasan Sekitar Kampus ITS Sukolilo. Adapun variabel tersebut telah melalui 3 tahap wawancara delphi (putaran) sehingga hasil terakhir menunjukkan validasi yang paling tepat. Adapun variabel-variabel tersebut, antara lain: Kebutuhan Ruang (Fisik), Densitas/Kepadatan Penduduk (Fisik), Kelengkapan Fasilitas Lingkungan (Fisik), Keberadaan Induk Semang Pada Hunian (Sosial), Interaksi Antara Mahasiswa Dan Masyarakat (Sosial), Pertambahan Penduduk Muda (Sosial), Bauran Mahasiswa dan Masyarakat (Budaya), Kepemilikan Properti (Ekonomi), Indekos Sebagai Investasi (Ekonomi), Kepemilikan Usaha Lain (Ekonomi), dan Harga Jual Tanah (Ekonomi). 


\section{KESIMPULAN}

1. Indikator Fisik yang menjadi faktor penentu antara lain: Kebutuhan Ruang Densitas/ Kepadatan Penduduk, Kelengkapan Fasilitas Lingkungan .

2. Indikator Sosial yang menjadi faktor penentu antara lain: Keberadaan Induk Semang pada Hunian, Interaksi Antara Mahasiswa dan Masyarakat, Pertambahan Penduduk Muda.

3. Indikator Budaya yang menjadi faktor penentu adalah Bauran Mahasiswa dan Masyarakat

4. Indikator Ekonomi yang menjadi faktor penentu antara lain: Kepemilikan Properti, Indekos sebagai Investasi, Kepemilikan Usaha Lain, Harga Jual Tanah.

\section{DAFTAR PUSTAKA}

[1] D. Smith, A. Alamel, S. Balsdon, and C. Kinton, "Studentification in Loughborough 2013."

[2] J. Anderson, "Studentification," 2011.

[3] S. Sabri, A. F. A. Nazri, and M. Ludin, "\&quot;Studentification” is it a key factor within the residential decision-making process in Kuala Lumpur?," in The 3rd South East Asian Technical University Consortium (SEATUC) Symposium, 2009.
[4] V. F. Zahra, "Faktor-faktor penyebab perubahan penggunaan lahan pada kampus sekitar kampus Institut Teknologi Sepuluh Nopember,’ Institut Teknologi Sepuluh Nopember, 2014.

[5] BAPPEDA Kota Surabaya, "Rencana Detail Tata Ruang UP. Kertajaya Tahun 2008-2018.” Surabaya, 2008.

[6] P. Hubbard, "Geographies of studentification and purpose-built student accommodation: Leading separate lives?,” Environ. Plan. A Econ. Sp., vol. 41, no. 8, pp. 1903-1923, Aug. 2009.

[7] Biro Pusat Statistik (BPS) Kota Surabaya, Statistik Daerah Kecamatan Sukolilo Tahun 2016. Surabaya: Biro Pusat Statistik (BPS) Kota Surabaya, 2016.

[8] J. L. Sage, "The micro-geographies of Studentification in Brighton and Hove,” University of Brighton, 2010.

[9] J. Hatch, C. Marcotte, J. Posik, H. S. Iii, and A. Thibodeau, "Confronting the Challenges of Studentification in Residential Orono Neighborhoods. Photo Credit: Michael Stapelton,” Orono, 2016.

[10] M. H. Muslim, H. A. Karim, I. C. Abdullah, and P. Ahmad, "Students' perception of residential satisfaction in the level of offcampus environment,” Procedia - Soc. Behav. Sci., vol. 105, pp. 684 696, Dec. 2013.

[11] G. D. Suradi, “Studentifikasi di kawasan Pogung Kidul, Yogyakarta,” Universitas Gadjah Mada, 2015.

[12] I. N. T. Prayoga, "keberlangsungan menetap penduduk asli pada kawasan di sekitar kampus UNDIP Tembalang sebagai permukiman Kota Semarang yang tergentrifikasi,” J. Pembang. Wil. KOTA, vol. 9, no. 1, pp. 1-10, Mar. 2013.

[13] J. Noor, Metodologi penelitian skripsi, tesis, disertasi dan karya ilmiah. Jakarta: Kencana Prenada Media Group, 2011. 